\title{
The Effect of Repeated Passaging on the Susceptibility of Human Proximal Tubular HK-2 Cells to Toxic Compounds
}

\author{
Jiří HANDL ${ }^{1}$, Jan ČAPEK ${ }^{1}$, Pavlína MAJTNEROVÁ ${ }^{1}$, Jana BÁČOVÁ ${ }^{1}$, Tomáš ROUŠAR ${ }^{1}$ \\ ${ }^{1}$ Department of Biological and Biochemical Sciences, Faculty of Chemical Technology, University \\ of Pardubice, Pardubice, Czech Republic
}

Received April 27, 2020

Accepted June 9, 2020

Epub Ahead of Print July 16, 2020

\begin{abstract}
Summary
The human proximal tubular HK-2 cell line is an immortalized cell line commonly used for studying proximal tubular toxicity. Even as their use is presently increasing, there unfortunately are no studies focused on functional changes in HK-2 cells associated with passaging. The aim of the present study, therefore, was to evaluate the functional stability of HK-2 cells during 13 weeks of continuous passaging after 6 and $24 \mathrm{~h}$ of treatment with model nephrotoxic compounds (i.e., acetaminophen, cisplatin, $\mathrm{CdCl}_{2}$ ). Short tandem repeat profile, the doubling time, cell diameter, glutathione concentration, and intracellular dehydrogenase activity were measured in HK-2 cells at each tested passage. The results showed that HK-2 cells exhibit stable morphology, cell size, and cell renewal during passaging. Mean doubling time was determined to be $54 \mathrm{~h}$. On the other hand, we observed a significant effect of passaging on the susceptibility of HK-2 cells to toxic compounds. The largest difference in results was found in both cadmium and cisplatin treated cells across passages. We conclude that the outcomes of scientific studies on HK-2 cells can be affected by the number of passages even after medium-term cultivation and passaging for 13 weeks.
\end{abstract}

\section{Key words}

HK-2 cells • Nephrotoxicity • Cell passaging • in vitro culture • Cell lines

\section{Corresponding author}

Tomáš Roušar, Department of Biological and Biochemical Sciences, Faculty of Chemical Technology, University of Pardubice, Studentska 573, 53210 Pardubice, Czech Republic. E-mail: Tomas.Rousar@upce.cz
In vitro cell models including primary cell cultures and cell lines are used in cytotoxicity screening (Popelová et al. 2018, Tong et al. 2017, Xia et al. 2013). While working with cell lines, it is necessary to follow basic cultivation techniques and elementary principles. Passage number is one of the important factors that informs about the cell line's age and that is essential for evaluating a cell line's growth integrity (Clynes 1998, Freshney 2005, Kwist et al. 2015). It is well established that cell phenotype can change during the process of passaging, and this may affect reproducibility of the results from in vitro experiments (Hughes et al. 2007, Reeves et al. 2018, Vasilevsky et al. 2013). Most studies assume that the number of passages in a cell line does not affect its phenotype and therefore the passage number is not mentioned. Some results have shown, however, that some non-cancer cell lines exhibit genetic heterogeneity and instability (Ben-David et al. 2018).

There are a number of animal and human cell lines that can be used to assess nephrotoxic properties (Kim 2016, Vrbová et al. 2016). The human cell lines are HEK293, IP-15, and HK-2 cells (Graham et al. 1977, L'Azou et al. 2006, Ryan et al. 1994, Vošahlíková and Svoboda 2011). The human proximal tubular HK-2 (Human Kidney-2) cell line is an immortalized cell line. The HK-2 cell line was originally prepared by transduction with human papilloma virus 16 (HPV-16) E6/E7 genes (Ryan et al. 1994). HK-2 cells grow in a monolayer and are suitable to studying proximal tubular toxicity of a variety of compounds (Racusen et al. 1997). The main advantage of $\mathrm{HK}-2$ cells is that they retain the 
basic morphological and functional properties of proximal tubular epithelial cells (Ryan et al. 1994). Therefore, HK-2 cells have been used in a number of recent studies focused on estimating proximal tubular injury (Du et al. 2010, Gao et al. 2013, García-Pastor et al. 2019, Schmidt et al. 2019, Wu et al. 2009, Yang et al. 2019b, Yang et al. 2019c, Zaza et al. 2015).

According to the PubMed database, as many as about 200 studies a year are now published that used HK2 cells for in vitro testing, and that frequency is increasing. Based upon the very recent scientific papers, only limited numbers of authors have reported the numbers of HK-2 cell passages they have used in their studies. Most of those have reported using passages in the ranges of $\leq 5$ passages (Devocelle et al. 2019, Gao et al. 2017, Handl et al. 2019, Huang et al. 2017, Lu et al. 2018), $\leq 20$ passages (Devocelle et al. 2019, Han et al. 2018, Huang et al. 2019, Lee et al. 2019b, Lu et al. 2018, Vrbová et al. 2016, Wang et al. 2006), or for even longer periods (Chang and Singh 2019, Wang et al. 2006). Meanwhile, a large number of presently existing scientific studies on HK-2 cells have not provided any information at all on the passage number (Amaral et al. 2017, Campos et al. 2018, Lee et al. 2019a, MedinaNavarro et al. 2019, Nho et al. 2018, Song et al. 2018, Yang et al. 2019b, Yeh et al. 2019). Surprisingly, only one study marginally estimated an effect of the number of passages on the results obtained in HK-2 cells (Lu et al. 2018) confirming the occurrence of differences in protein expressions between low (6) and high (18) number of passages. Due to the lack of information on probable functional changes in $\mathrm{HK}-2$ cells during continuous passaging, we report here a study on evaluation of functional stability and susceptibility of HK-2 cells to model toxic compounds after 13 weeks of passaging (i.e., in passages 3-15).

Human kidney (HK-2) cells were purchased from the American Type Culture Collection (ATCC, Manassas, VA, USA). The cells were cultured according to a published protocol (Handl et al. 2019, Hauschke et al. 2017) in supplemented Dulbecco's modified Eagle's medium $(\mathrm{DMEM} / \mathrm{F} 12=1: 1)$ with $5 \%(\mathrm{v} / \mathrm{v})$ fetal bovine serum, $1 \mathrm{mM}$ pyruvate, $10 \mu \mathrm{g} / \mathrm{ml}$ insulin, $5.5 \mu \mathrm{g} / \mathrm{ml}$ transferrin, $5 \mathrm{ng} / \mathrm{ml}$ sodium selenite, $50 \mu \mathrm{g} / \mathrm{ml}$ penicillin, $50 \mu \mathrm{g} / \mathrm{ml}$ streptomycin, and $5 \mathrm{ng} / \mathrm{ml}$ epidermal growth factor. The cells were removed by adding trypsin-EDTA and passaged when they reached $75-85 \%$ confluence. After every 7 days, cells were passaged, counted, and then the optimal amount $\left(4 \times 10^{5}\right.$ cells $)$ was seeded into
$10 \mathrm{ml}$ of cultivation medium on a new $75 \mathrm{~cm}^{2}$ culture vessel. All experiments were conducted using the HK-2 cells between passages 3 and 15. The HK-2 cells were tested for mycoplasma contamination using the MycoAlert Mycoplasma Detection Kit (Lonza). All cells used in the experiments were mycoplasma free.

We analyzed functional parameters of the cells during passaging, i.e. short tandem repeat analysis, cell diameter and doubling time. Short tandem repeat (STR) analysis (i.e., DNA fingerprinting) was used for HK-2 cell line authentication in passages 3, 9, and 15 using a commercial kit (Generi Biotech a.g., Czech Republic). STR analysis was conducted by Generi Biotech, Ltd. (Czech Republic). We used seventeen selected autosomal polymorphisms (CSF1PO, D13S317, D16S539, D18S51, D19S433, D21S11, D2S1338, D3S1358, D5S818, D7S820, D8S1179, FGA, Penta D, Penta E, TH01, TPOX, and vWA) and amelogenin to compare the STR profile with established STR databases. Mean diameter of the HK-2 cells was evaluated using the CASY model TT cell counter and analyzer (Roche, Germany). Doubling time (i.e., the time needed to double the cell population) was calculated from the number of seeded cells, number of viable cells, and time elapsed from cell seeding into the culture vessel until their passaging and counting.

HK-2 cells were seeded into 96-well plates at density $3 \times 10^{4}$ cells/well in $100 \mu \mathrm{l}$ of culture medium. After $24 \mathrm{~h}$, to induce cell impairment, the HK-2 cells were treated with $10 \mathrm{mM}$ acetaminophen, $100 \mu \mathrm{M}$ cisplatin, $50 \mu \mathrm{M}$ tert-butylhydroperoxide, and $100 \mu \mathrm{M}$ $\mathrm{CdCl}_{2}$. Cells were treated for 6 and $24 \mathrm{~h}$. The WST-1 test to evaluate dehydrogenase activity (Roche, Germany) and glutathione assay were used for characterizing cell damage. After treatment, the WST-1 reagent was added to the cultured cells (1:10 final dilution) (Hauschke et al. 2017). The cells were incubated in a gassed atmosphere $\left(5 \% \mathrm{CO}_{2}\right)$ for $60 \mathrm{~min}$ and the absorbance change $(0-1 \mathrm{~h})$ was measured spectrophotometrically at wavelength $440 \mathrm{~nm}$ using a Tecan Infinite M200 plate reader (Tecan, Austria) and expressed as the change of absorbance during $1 \mathrm{~h}$ and also relative to controls in percentage terms. Glutathione (GSH) levels were measured using an optimized bimane assay (Čapek et al. 2017). After 6 or $24 \mathrm{~h}$ of incubation, $20 \mu \mathrm{l}$ of the bimane solution was added to cells and the measurement was started. The fluorescence $(E x / E m=394 / 490 \mathrm{~nm})$ was measured for 20 min using a Tecan Infinite M200 fluorescence reader incubated at $37{ }^{\circ} \mathrm{C}$. The fluorescence was expressed as 
the slope of change in fluorescence over time. The GSH levels were expressed as percentages relative to those in control cells $(=100 \%)$. All experiments were repeated two or three times independently over a course of 8 months. All values were measured at least in quadruplicate during an experiment. The results on cell viability and GSH levels are expressed as means $\pm \mathrm{SD}$ (OriginPro 9.0.0, USA). The effect of number of passages and toxic compounds on the cell impairment was tested using Two-way ANOVA ( $\mathrm{p}=0.05$, OriginPro 9.0.0, USA).

The STR analysis proved $100 \%$ conformity of HK-2 cells with the reference standard in all tested passages and also confirmed no shift of STR sequences in the HK-2 cells. The diameters of viable HK-2 cells ranged 17.4-18.6 $\mu \mathrm{m}$. The mean diameter of HK-2 cells calculated across all passages was $18.2 \mu \mathrm{m}$. Doubling time ranged between $47.3 \mathrm{~h}$ and $61.7 \mathrm{~h}$. The mean doubling time across all passages was $53.7 \mathrm{~h}$, and we observed no significant relationship between doubling time and cell passage number. The doubling time is in accordance with characteristics for the HK-2 cell line presented by ATCC.

In addition to estimation of the functional parameters in untreated HK-2 cells, we estimated the effect of continuous passaging on the susceptibility of HK-2 cells to model nephrotoxic compounds. To induce the toxicity, we used toxic substances differing in their mechanisms of toxicity, including tert-butylhydroperoxide (tBHP) to induce oxidative stress, two drugs, acetaminophen (APAP) and cisplatin (CisPt), and $\mathrm{CdCl}_{2}$ as a heavy metal. Tested concentrations of the compounds were chosen according to previous toxicological studies relating to cisplatin (Genc et al.
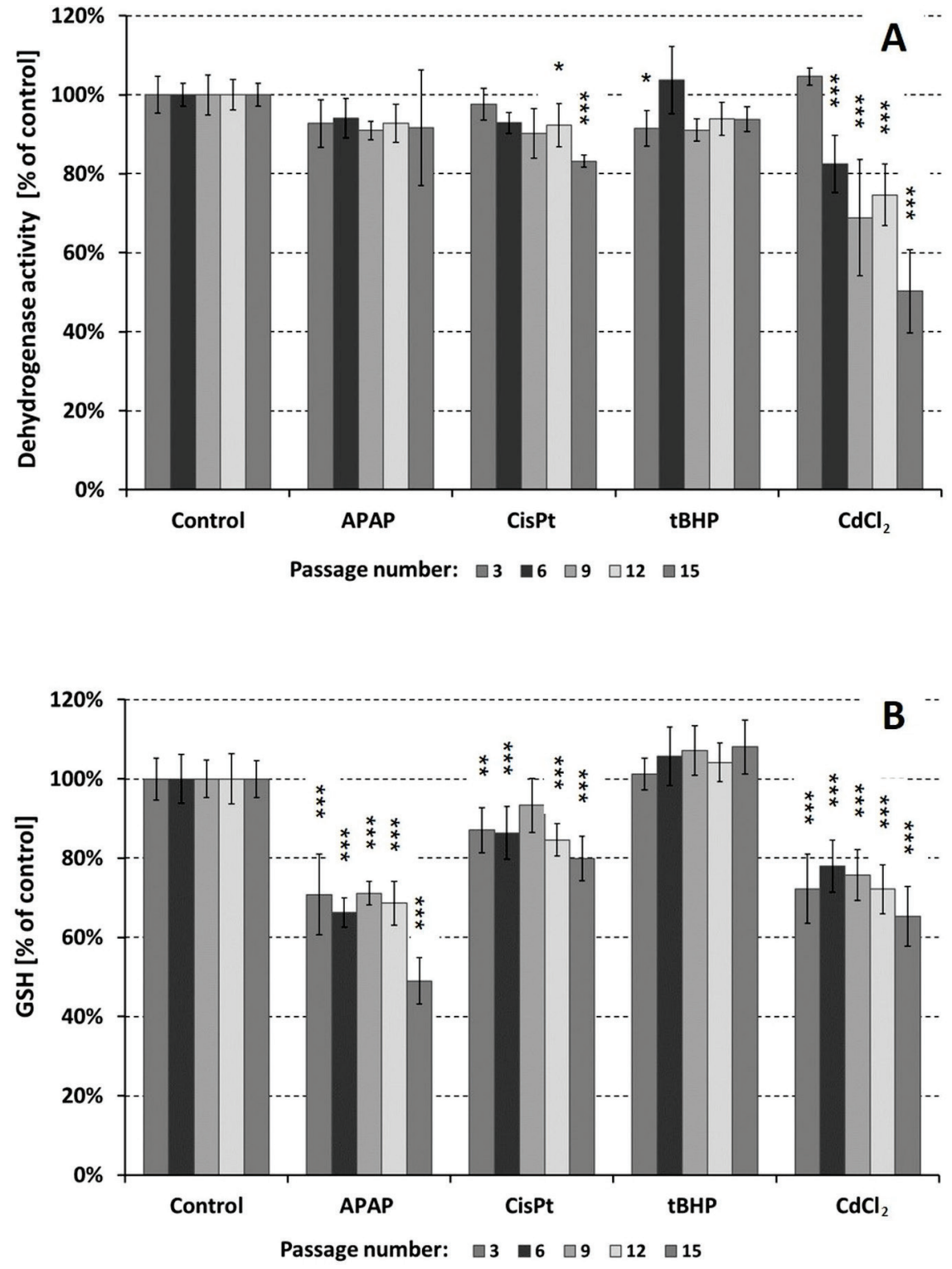

Fig. 1. Estimation of cell impairment in HK-2 cells after $6 \mathrm{~h}$ of treatment during repeated passaging Acetaminophen (APAP, $10 \mathrm{mM}$ ), cisplatin (CisPt, $100 \mu \mathrm{M})$, tertbutylhydroperoxide (tBHP, $50 \mu \mathrm{M})$, and $\mathrm{CdCl}_{2} \quad(\mathrm{Cd}, \quad 100 \mu \mathrm{M})$ A) Intracellular dehydrogenase activity in $\mathrm{HK}-2$ cells in passages 3-15 was determined using the WST-1 test B) Intracellular GSH levels of $\mathrm{HK}-2$ cells in each of passages 3-15 were determined using monochlorobimane assay Results are expressed as means $\pm \mathrm{SD}$ (control $=100 \%, \mathrm{n}=8-12$, 3 independent experiments) One-way ANOVA with post-hoc test were used for comparison of means with control cells at appropriate number of passages $(*, p<0.05, * *, p<0.01$, $* * *, p<0.001$ ). 
2014, Huang et al. 2015, Kim et al. 2014), cadmium (Fujiki et al. 2013, Handl et al. 2019, Kim et al. 2014), acetaminophen (Wu et al. 2009), and tBHP (Hauschke et al. 2017).

HK-2 cells in passages $3,6,9,12$ and 15 were treated with toxic compounds for 6 and 24 h. Indeed, we determined the significant effect of a number of passages on decrease of dehydrogenase activity and the extent of glutathione depletion according to Two-way ANOVA test after 6 and $24 \mathrm{~h}$. After $6 \mathrm{~h}$ of treatment, the intracellular dehydrogenase activity showed significant decrease in comparison with control cells of the corresponding passage number in toxic compounds, especially in Cd treated cells (Fig. 1A). Based on the WST-1 test results, we found also a significant relation of the number of passage and the extent of decreasing cell viability in HK-2 cells treated with a toxic compound $(p<0.001)$. In addition to the glutathione reduction caused by $10 \mathrm{mM}$ APAP, $100 \mu \mathrm{M} \mathrm{CisPt}$, and $100 \mu \mathrm{M} \mathrm{CdCl}_{2}$ in comparison with controls of the corresponding passage number, the effect of passaging on the extent of glutathione depletion in toxic compounds was found $(p<0.001)$ (Fig. 1B).

After $24 \mathrm{~h}$ of incubation, deepening of toxic acting of tested compounds was found. In addition, the outcomes of the WST-1 test $(p<0.001)$ and glutathione assay $(p<0.001)$ also showed a significant effect of the number of passage on the estimated level of toxicity. In Fig. 2AB, the increasing cell impairment was especially found in CisPt and APAP treated HK-2 cells.
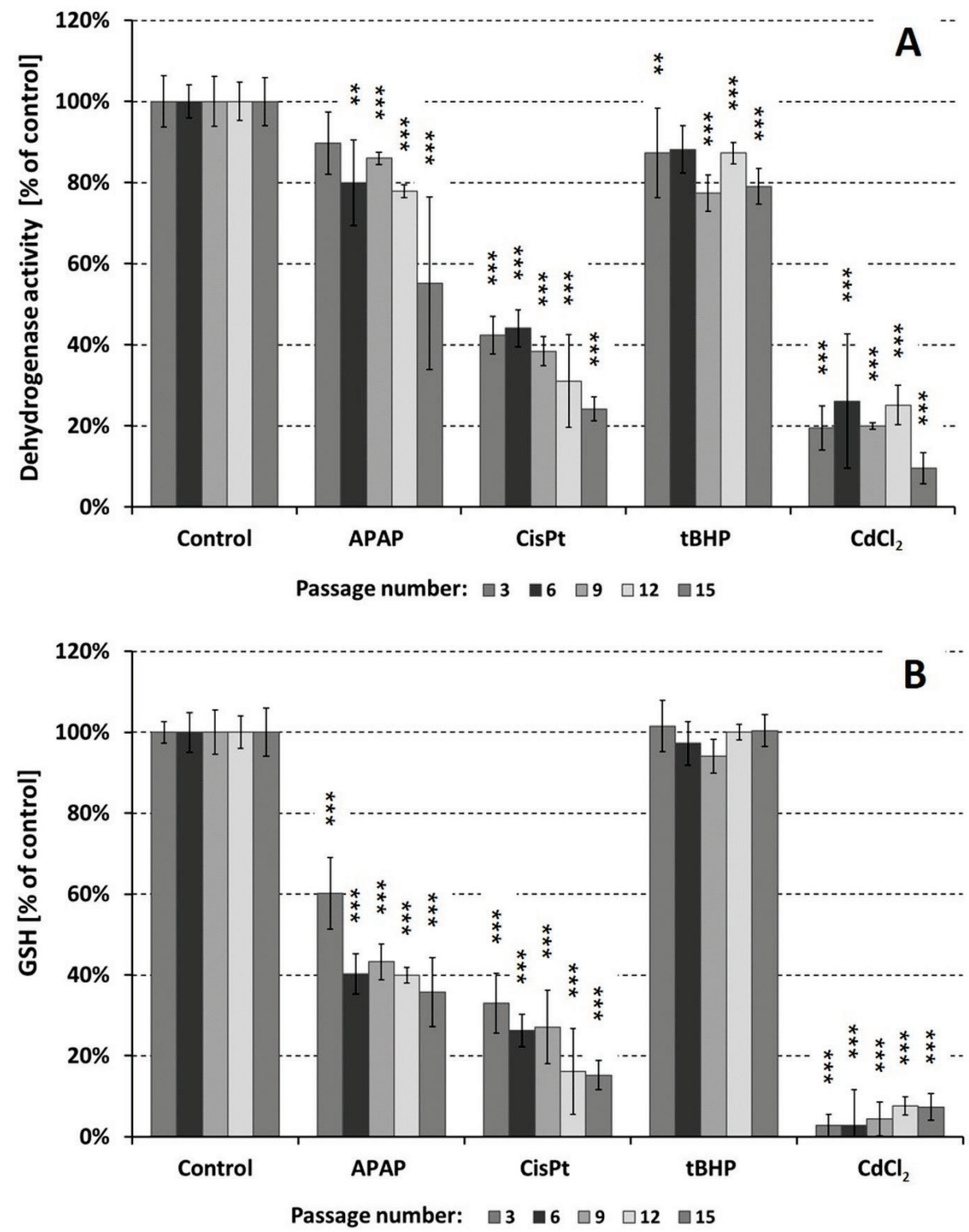

Fig. 2. Estimation of cell impairment in HK-2 cells after $24 \mathrm{~h}$ of treatment during repeated passaging Acetaminophen (APAP, $10 \mathrm{mM}$ ), cisplatin (CisPt, $100 \mu \mathrm{M}$ ), tertbutylhydroperoxide (tBHP, 50 $\mu \mathrm{M})$, and $\mathrm{CdCl}_{2}(\mathrm{Cd}, 100 \mu \mathrm{M})$ A) Intracellular dehydrogenase activity in HK-2 cells in each of passages 3-15 was determined using the WST-1 test B) Intracellular GSH levels of HK-2 cells in passages 3-15 were determined using monochlorobimane assay Results are expressed as means \pm SD (control $=100 \%, \mathrm{n}=8-12$, 3 independent experiments) One-way ANOVA with post-hoc test were used for comparison of means with control cells at appropriate number of passages $(* *, p<0.01, * * *, p<$ 0.001). 
According to determined decrease of cell viability and glutathione depletion in $\mathrm{HK}-2$ cells, the extent of cell damage reported in present study is fully comparable with the outcomes and toxin concentrations reported in a number of other studies on APAP (Ruan et al. 2019, Zhang et al. 2007), CisPt (Oh et al. 2017, Yang et al. 2019a), and $\mathrm{CdCl}_{2}$ (Fujiki et al. 2019, Ge et al. 2018, Chou et al. 2019, Kim et al. 2014). On the other hand, our findings on significance of the relation of cell damage and number passage is not allowed to discuss with comparable reports on the HK-2 cell line. Some studies focusing on this issue have shown that biological characteristics can be changed not only in stem cell cultures (Kwist et al. 2015) but also in transfected cell lines (O'Driscoll et al. 2006) and definitely in tumor cell lines (Bušek et al. 2008, Jin et al. 2017, Roberts et al.
2018, Zeng et al. 2018) which outcomes can be supported by our study.

In conclusion, we report here that HK-2 cell line did not possess stable susceptibility to model toxic compounds during continuous passaging for 13 weeks. Based on presented results, we conclude that the outcomes of experiments obtained using the HK-2 cell line passaged are supposed to be considered with regard to the number of passages.

\section{Acknowledgement}

The study was supported by the grant of the Czech Science Foundation No 19-11867S.

\section{Conflict of Interest}

There is no conflict of interest.

\section{References}

AMARAL M, GIRARD M, Álvarez R, PATON A, PATON J, REPETTO H, SACERDOTI F, IBARRA C: Ouabain protects human renal cells against the cytotoxic effects of shiga toxin type 2 and subtilase cytotoxin. Toxins 9: 1-14, 2017. https://doi.org/10.3390/toxins9070226

BEN-DAVID U, SIRANOSIAN B, HA G, TANG H, OREN Y, HINOHARA K, STRATHDEE CA, DEMPSTER J, LYONS NJ, BURNS R, NAG A, KUGENER G, CIMINI B, TSVETKOV P, MARUVKA YE, O'ROURKE R, GARRITY A, TUBELLI AA, BANDOPADHAYAY P, TSHERNIAK A, VAZQUEZ F, WONG B, BIRGER C, GHANDI M, THORNER AR, BITTKER JA, MEYERSON M, GETZ G, BEROUKHIM R, GOLUB TR: Genetic and transcriptional evolution alters cancer cell line drug response. Nature 560: 325-330, 2018. https://doi.org/10.1038/s41586-018-0409-3

BUŠEK P, STREMEŇOVÁ J, KŘEPELA E, ŠEDO A: Modulation of substance P signaling by dipeptidyl peptidase-IV enzymatic activity in human glioma cell lines. Physiol Res 57: 443-449, 2008.

CAMPOS MAA, DE ALMEIDA LA, GROSSI MF, TAGLIATI CA: In vitro evaluation of biomarkers of nephrotoxicity through gene expression using gentamicin. J Biochem Mol Toxicol 32: e22189, 2018. https://doi.org/10.1002/jbt.22189

CLYNES M: Animal cell culture techniques. Springer-Verlag Berlin and Heidelberg GmbH \& Co KG, New York, p 618, 1998. https://doi.org/10.1007/978-3-642-80412-0

ČAPEK J, HAUSCHKE M, BRU゚ČKOVÁ L, ROUŠAR T: Comparison of glutathione levels measured using optimized monochlorobimane assay with those from ortho-phthalaldehyde assay in intact cells. J Pharmacol Toxicol Methods 88: 40-45, 2017. https://doi.org/10.1016/j.vascn.2017.06.001

DEVOCELLE A, LECRU L, FRANÇOIS H, DESTERKE C, GALLERNE C, EID P, ESTELLE O, AZZARONE B, GIRON-MICHEL J: Inhibition of TGF- $\beta 1$ signaling by IL-15: A novel role for IL-15 in the control of renal epithelial-mesenchymal transition: IL-15 counteracts TGF- $\beta 1$-induced EMT in renal fibrosis. Int J Cell Biol 2019: 1-15, 2019. https://doi.org/10.1155/2019/9151394

DU B, MA L-M, HUANG M-B, ZHOU H, HUANG H-L, SHAO P, CHEN Y-Q, QU L-H: High glucose downregulates miR-29a to increase collagen IV production in HK-2 cells. FEBS Lett 584: 811-816, 2010. https://doi.org/10.1016/j.febslet.2009.12.053

FRESHNEY RI: Culture of animal cells: A manual of basic techniques. John Wiley \& Sons 2005 , pp 672. https://doi.org/10.1002/9780471747598

FUJIKI K, INAMURA H, MATSUOKA M: PI3K signaling mediates diverse regulation of ATF4 expression for the survival of HK-2 cells exposed to cadmium. Arch Toxicol 88: 403-414, 2013. https://doi.org/10.1007/s00204$\underline{013-1129-y}$ 
FUJIKI K, INAMURA H, SUGAYA T, MATSUOKA M: Blockade of ALK4/5 signaling suppresses cadmium- and erastin-induced cell death in renal proximal tubular epithelial cells via distinct signaling mechanisms. Cell Death Differ 26: 2371-2385, 2019. https://doi.org/10.1038/s41418-019-0307-8

GAO S, CHEN T, CHOI M-Y, LIANG Y, XUE J, WONG Y-S: Cyanidin reverses cisplatin-induced apoptosis in HK-2 proximal tubular cells through inhibition of ROS-mediated DNA damage and modulation of the ERK and AKT pathways. Cancer Lett 333: 36-46, 2013. https://doi.org/10.1016/j.canlet.2012.12.029

GAO Z, ZHU W, ZHANG H, LI Z, CUI T: The influence of fasudil on renal proximal tubular cell epithelialmesenchymal transition induced by parathormone. Ren Fail 39: 575-581, 2017. https://doi.org/10.1080/0886022X.2017.1349677

GARCÍA-PASTOR C, BLÁZQUEZ-SERRA R, BOSH RJ, LUCIO-CAZAÑA FJ, FERNÁNDEZ-MARTÍNEZ AB: Apoptosis and cell proliferation in proximal tubular cells exposed to apoptotic bodies Novel pathophysiological implications in cisplatin-induced renal injury. Biochim Biophys Acta - Mol Basis Dis 1865: 2504-2515, 2019. https://doi.org/10.1016/j.bbadis.2019.06.008

GE Z, DIAO H, JI X, LIU Q, ZHANG X, WU Q: Gap junctional intercellular communication and endoplasmic reticulum stress regulate chronic cadmium exposure induced apoptosis in HK-2 cells. Toxicol Lett 288: 35-43, 2018. https://doi.org/10.1016/j.toxlet.2018.02.013

GENC G, KILINC V, BEDIR A, OZKAYA O: Effect of creatine and pioglitazone on HK-2 cell line cisplatin nephrotoxicity. Ren Fail 36: 1104-1107, 2014. https://doi.org/10.3109/0886022X.2014.926755

GRAHAM FL, SMILEY J, RUSSELL WC, NAIRN R: Characteristics of a human cell line transformed by DNA from human adenovirus type 5. J Gen Virol 36: 59-72, 1977. https://doi.org/10.1099/0022-1317-36-1-59

HAN M, LI Y, WEN D, LIU M, MA Y, CONG B: NGAL protects against endotoxin-induced renal tubular cell damage by suppressing apoptosis. BMC Nephrol 19: 1-10, 2018. https://doi.org/10.1186/s12882-018-0977-3

HANDL J, ČAPEK J, MAJTNEROVÁ P, PETIRA F, HAUSCHKE M, ROUŠAROVÁ E, ROUŠAR T: Transient increase in cellular dehydrogenase activity after cadmium treatment precedes enhanced production of reactive oxygen species in human proximal tubular kidney cells. Physiol Res 68: 481-490, 2019. https://doi.org/10.33549/physiolres.934121

HAUSCHKE M, ROUŠAROVÁ E, FLÍDR P, ČAPEK J, LIBRA A, ROUŠAR T: Neutrophil gelatinase-associated lipocalin production negatively correlates with HK-2 cell impairment: Evaluation of NGAL as a marker of toxicity in HK-2 cells. Toxicol In Vitro 39: 52-57, 2017. https://doi.org/10.1016/j.tiv.2016.11.012

HUANG F, ZHAO Y, WANG Q, HILLEBRANDS J-L, BORN JVD, JI L, AN T, QIN G: Dapagliflozin attenuates renal tubulointerstitial fibrosis associated with type 1 diabetes by regulating STAT1/TGF $\beta 1$ signaling. Front Endocrinol 10: 1-13, 2019. https://doi.org/10.3389/fendo.2019.00441

HUANG H, ZHENG F, DONG X, WU F, WU T, LI H: Allicin inhibits tubular epithelial-myofibroblast transdifferentiation under high glucose conditions in vitro. Exp Ther Med 13: 254-262, 2017. https://doi.org/10.3892/etm.2016.3913

HUANG JX, KAESLIN G, RANALL MV, BLASKOVICH MA, BECKER B, BUTLER MS, LITTLE MH, LASH LH, COOPER MA: Evaluation of biomarkers for in vitro prediction of drug-induced nephrotoxicity: comparison of HK-2, immortalized human proximal tubule epithelial, and primary cultures of human proximal tubular cells. Pharmacol Res Perspect 3: 1-14, 2015. https://doi.org/10.1002/prp2.148

HUGHES P, MARSHALL D, REID Y, PARKES H, GELBER C: The costs of using unauthenticated, over-passaged cell lines: how much more data do we need? Biotechniques 43: 575-584, 2007. https://doi.org/10.2144/000112598

CHANG Y-W, SINGH KP: Nicotine-induced oxidative stress contributes to EMT and stemness during neoplastic transformation through epigenetic modifications in human kidney epithelial cells. Toxicol Appl Pharmacol 374: 65-76, 2019. https://doi.org/10.1016/j.taap.2019.04.023

CHOU X, DING F, ZHANG X, DING X, GAO H, WU Q: Sirtuin-1 ameliorates cadmium-induced endoplasmic reticulum stress and pyroptosis through XBP-1s deacetylation in human renal tubular epithelial cells. Arch Toxicol 93: 965-986, 2019. https://doi.org/10.1007/s00204-019-02415-8

JIN W, PENINGTON CJ, MCCUE SW, SIMPSON MJ: A computational modelling framework to quantify the effects of passaging cell lines. Plos One 12: 1-16, 2017. https://doi.org/10.1371/journal.pone.0181941

KIM J: Poly(ADP-Ribose) polymerase activation induces high mobility group box 1 release from proximal tubular cells during cisplatin nephrotoxicity. Physiol Res 65: 333-340, 2016. https://doi.org/10.33549/physiolres.932948 
KIM SY, SOHN S-J, WON AJ, KIM HS, MOON A: Identification of noninvasive biomarkers for nephrotoxicity using HK-2 human kidney epithelial cells. Toxicol Sci 140: 247-258, 2014. https://doi.org/10.1093/toxsci/kfu096

KWIST K, BRIDGES WC, BURG KJL: The effect of cell passage number on osteogenic and adipogenic characteristics of D1 cells. Cytotechnology 68: 1661-1667, 2015. https://doi.org/10.1007/s10616-015-9883-8

L'AZOU B, DUBUS I, OHAYON-COURTÈS C, CAMBAR J: Human glomerular mesangial IP15 cell line as a suitable model for in vitro cadmium cytotoxicity studies. Cell Biol Toxicol 23: 267-278, 2006. https://doi.org/10.1007/s10565-006-0888-0

LEE CP, NITHIYANANTHAM S, HSU HT, YEH KT, KUO TM, KO YC: ALPK1 regulates streptozotocin induced nephropathy through CCL2 and CCL5 expressions. J Cell Mol Med 23: 7699-7708, 2019 a. https://doi.org/10.1111/jcmm.14643

LEE YP, CHO Y, KIM EJ, LEE H, CHOI HY, WANG HJ, KANG ES, KIM YS, KIM MS, KIM BS: Reduced expression of pyruvate kinase in kidney proximal tubule cells is a potential mechanism of pravastatin altered glucose metabolism. Sci Rep 9: 1-8, 2019b. https://doi.org/10.1038/s41598-019-39461-2

LU Y-T, MA X-L, XU Y-H, HU J, WANG F, QIN W-Y, XIONG W-Y: A fluorescent glucose transport assay for screening SGLT2 inhibitors in endogenous SGLT2-expressing HK-2 cells. Nat Prod Bioprospect 9: 13-21, 2018. https://doi.org/10.1007/s13659-018-0188-4

MEDINA-NAVARRO R, TORRES-RAMOS YD, GUZMÁN-GRENFELL AM, DÍAZ-FLORES M, LEÓN-REYES G, HICKS G JJ: Lysosomal dysfunction induced by changes in albumin's tertiary structure: Potential key factor in protein toxicity during diabetic nephropathy. Life Sci 230: 197-207, 2019. https://doi.org/10.1016/j.1fs.2019.05.069

NHO J-H, JUNG H-K, LEE M-J, JANG J-H, SIM M-O, JEONG D-E, CHO H-W, KIM J-C: Beneficial effects of cynaroside on cisplatin-induced kidney injury in vitro and in vivo. Toxicol Res 34: 133-141, 2018. https://doi.org/10.5487/TR.2018.34.2.133

O'DRISCOLL L, GAMMELL P, MCKIERNAN E, RYAN E, JEPPESEN PB, RANI S, CLYNES M: Phenotypic and global gene expression profile changes between low passage and high passage MIN-6 cells. J Endocrinol 191: 665-676, 2006. https://doi.org/10.1677/joe.1.06894

OH S-M, PARK G, LEE SH, SEO C-S, SHIN H-K, OH D-S: Assessing the recovery from prerenal and renal acute kidney injury after treatment with single herbal medicine via activity of the biomarkers HMGB1, NGAL and KIM-1 in kidney proximal tubular cells treated by cisplatin with different doses and exposure times. BMC Complement Altern Med 17: 1-9, 2017. https://doi.org/10.1186/s12906-017-2055-y

POPELOVÁ A, KÁKONOVÁ A, HRUBÁ L, KUNEŠ J, MALETÍNSKÁ L, ŽELEZNÁ B: Potential neuroprotective and anti-apoptotic properties of a long-lasting stable analog of ghrelin: an in vitro study using SH-SY5Y cells. Physiol Res 67: 339-346, 2018. https://doi.org/10.33549/physiolres.933761

RACUSEN LC, MONTEIL C, SGRIGNOLI A, LUCSKAY M, MAROUILLAT S, RHIM JGS, MORIN J-P: Cell lines with extended in vitro growth potential from human renal proximal tubule: Characterization, response to inducers, and comparison with established cell lines. J Lab Clin Med 129: 318-329, 1997. https://doi.org/10.1016/S0022-2143(97)90180-3

REEVES SR, BARROW KA, WHITE MP, RICH LM, NAUSHAB M, DEBLEY JS: Stability of gene expression by primary bronchial epithelial cells over increasing passage number. BMC Pulmonar Med 18: 1-11, 2018. https://doi.org/10.1186/s12890-018-0652-2

ROBERTS DD, TACIAK B, BIAŁASEK M, BRANIEWSKA A, SAS Z, SAWICKA P, KIRAGA Ł, RYGIEL T, KRÓL M: Evaluation of phenotypic and functional stability of RAW 264.7 cell line through serial passages. Plos One 13: e0198943, 2018. https://doi.org/10.1371/journal.pone.0198943

RUAN H, WANG L, WANG J, SUN H, HE X, LI W, ZHANG J: Sika deer antler protein against acetaminopheninduced oxidative stress and apoptosis in HK-2 cells via activating Nrf2/keap1/HO-1 pathway. J Food Biochem 00: e13067, 2019. https://doi.org/10.1111/jfbc.13067

RYAN MJ, JOHNSON G, KIRK J, FUERSTENBERG SM, ZAGER RA, TOROK-STORB B: HK-2: An immortalized proximal tubule epithelial cell line from normal adult human kidney. Kidney Int 45: 48-57, 1994. https://doi.org/10.1038/ki.1994.6

SCHMIDT HHHW, CHO S, YU S-L, KANG J, JEONG BY, LEE HY, PARK CG, YU Y-B, JIN D-C, HWANG W-M, YUN S-R, SONG HS, PARK MH, YOON S-H: NADPH oxidase 4 mediates TGF- $\beta 1 /$ Smad signaling pathway induced acute kidney injury in hypoxia. Plos One 14: e0219483, 2019. https://doi.org/10.1371/journal.pone.0219483 
SONG M-F, YANG Y, YI Z-W, ZHANG Z-Q, SHEN X-D, HU G-H, ZHU Y-F: Sema 3A as a biomarker of the activated mTOR pathway during hexavalent chromium-induced acute kidney injury. Toxicol Lett 299: 226-235, 2018. https://doi.org/10.1016/j.toxlet.2018.09.005

TONG Z-B, HOGBERG H, KUO D, SAKAMURU S, XIA M, SMIRNOVA L, HARTUNG T, GERHOLD D: Characterization of three human cell line models for high-throughput neuronal cytotoxicity screening. J Appl Toxicol 37: 167-180, 2017. https://doi.org/10.1002/jat.3334

VASILEVSKY NA, BRUSH MH, PADDOCK H, PONTING L, TRIPATHY SJ, LAROCCA GM, HAENDEL MA: On the reproducibility of science: unique identification of research resources in the biomedical literature. Peer J 1: e148, 2013. https://doi.org/10.7717/peerj.148

VOŠAHLÍKOVÁ M, SVOBODA P: The influence of monovalent cations on trimeric G protein Gil $\alpha$ activity in HEK293 cells stably expressing DOR-Gi1 $\alpha$ (Cys351-Ile351) fusion protein. Physiol Res 60: 541-547, 2011. https://doi.org/10.33549/physiolres.932096

VRBOVÁ M, ROUŠAROVÁ E, BRŮČKOVÁ L, ČESLA P, ROUŠAR T: Characterization of acetaminophen toxicity in human kidney HK-2 cells. Physiol Res 65: 627-635, 2016. https://doi.org/10.33549/physiolres.933158

WANG Q, LU Y, YUAN M, DARLING IM, REPASKY EA, MORRIS ME: Characterization of monocarboxylate transport in human kidney HK-2. Cells Mol Pharm 3: 675-685, 2006. https://doi.org/10.1021/mp060037b

WU Y, CONNORS D, BARBER L, JAYACHANDRA S, HANUMEGOWDA UM, ADAMS SP: Multiplexed assay panel of cytotoxicity in HK-2 cells for detection of renal proximal tubule injury potential of compounds. Toxicol in Vitro 23: 1170-1178, 2009. https://doi.org/10.1016/j.tiv.2009.06.003

XIA T, HAMILTON RF, BONNER JC, CRANDALL ED, ELDER A, FAZLOLLAHI F, GIRTSMAN TA, KIM K, MITRA S, NTIM SA, ORR G, TAGMOUNT M, TAYLOR AJ, TELESCA D, TOLIC A, VULPE CD, WALKER AJ, WANG X, WITZMANN FA, WU N, XIE Y, ZINK JI, NEL A, HOLIAN A: Interlaboratory evaluation of in vitro cytotoxicity and inflammatory responses to engineered nanomaterials: The NIEHS nano GO consortium. Environ Health Perspect 121: 683-690, 2013. https://doi.org/10.1289/ehp.1306561

YANG A, LIU F, GUAN B, LUO Z, LIN J, FANG W, LIU L, ZUO W: p53 induces miR-199a-3p to suppress mechanistic target of rapamycin activation in cisplatin-induced acute kidney injury. J Cell Biochem 120: 17625-17634, 2019a. https://doi.org/10.1002/jcb.29030

YANG G, MA H, WU Y, ZHOU B, ZHANG C, CHAI C, CAO Z: Activation of TRPC6 channels contributes to (+)-conocarpan-induced apoptotic cell death in HK-2 cells. Food Chem Toxicol 129: 281-290, 2019b. https://doi.org/10.1016/j.fct.2019.04.061

YANG K-J, KIM JH, CHANG YK, PARK CW, KIM SY, HONG YA: Inhibition of xanthine oxidoreductase protects against contrast-induced renal tubular injury by activating adenosine monophosphate-activated protein kinase. Free Radic Biol Med 145: 209-220, 2019c. https://doi.org/10.1016/j.freeradbiomed.2019.09.027

YEH IJ, WANG T-Y, LIN J-C, LIN T-J, CHANG J-S, YEN M-C, LIU Y-H, WU P-L, CHEN F-W, SHIH Y-L, PENG C-Y: Optimal regimen of n-acetylcysteine on chromium-induced renal cell damage. Metabolites 9: 172, 2019. https://doi.org/10.3390/metabo9090172

ZAZA G, MASOLA V, GRANATA S, BELLIN G, GASSA DA, ONISTO M, GAMBARO G, LUPO A: Sulodexide alone or in combination with low doses of everolimus inhibits the hypoxia-mediated epithelial to mesenchymal transition in human renal proximal tubular cells. J Nephrol 28: 431-440, 2015. https://doi.org/10.1007/s40620$\underline{015-0216-\mathrm{y}}$

ZENG Y, WANG X, WANG J, YI R, LONG H, ZHOU M, LUO Q, ZHAI Z, SONG Y, QI S: The tumorgenicity of glioblastoma cell line U87MG decreased during serial in vitro passage. Cell Mol Neurobiol 38: 1245-1252, 2018. https://doi.org/10.1007/s10571-018-0592-7

ZHANG L, MU X, FU J, ZHOU Z: In vitro cytotoxicity assay with selected chemicals using human cells to predict target-organ toxicity of liver and kidney. Toxicol In Vitro 21: 734-740, 2007. https://doi.org/10.1016/j.tiv.2007.01.013 